\title{
BRDOKHBVEN
}

NATIONAL LABORATORY

BNL-106158-2014-IR

\section{Cord Wood Testing in a Non-Catalytic Wood Stove}

\author{
T. Butcher, R. Trojanowski and G. Wei
}

June $30 ; 2014$

\author{
Sustainable Energy Technologies Department \\ Brookhaven National Laboratory
}

\section{U. S. Environmental Protection Agency under contract No. EP-D-10-096, WA 4-04 EC/R Incorporated, Prime Contractor}




\section{DISCLAIMER}

This report was prepared as an account of work sponsored by an agency of the United States Government. Neither the United States Government nor any agency thereof, nor any of their employees, nor any of their contractors, subcontractors, or their employees, makes any warranty, express or implied, or assumes any legal liability or responsibility for the accuracy, completeness, or any third party's use or the results of such use of any information, apparatus, product, or process disclosed, or represents that its use would not infringe privately owned rights. Reference herein to any specific commercial product, process, or service by trade name, trademark, manufacturer, or otherwise, does not necessarily constitute or imply its endorsement, recommendation, or favoring by the United States Government or any agency thereof or its contractors or subcontractors. The views and opinions of authors expressed herein do not necessarily state or reflect those of the United States Government or any agency thereof. 


\title{
Cord Wood Testing in a Non-Catalytic Wood Stove
}

Final Report

Prepared for:

U.S. Environmental Protection Agency under contract No. EP-D-10-096, WA 4-04 EC/R Incorporated, Prime Contractor

\author{
Prepared by: \\ Brookhaven National Laboratory \\ T. Butcher, R. Trojanowski, G. Wei \\ June 30,2014
}




\section{Abstract}

EPA Method 28 and the current wood stove regulations have been in-place since 1988. Recently, EPA proposed an update to the existing NSPS for wood stove regulations ${ }^{1}$ which includes a plan to transition from the current crib wood fuel to cord wood fuel for certification testing. Cord wood is seen as generally more representative of field conditions while the crib wood is seen as more repeatable. In any change of certification test fuel, there are questions about the impact on measured results and the correlation between tests with the two different fuels. The purpose of the work reported here is to provide data on the performance of a noncatalytic stove with cord wood. The stove selected has previously been certified with crib wood which provides a basis for comparison with cord wood. Overall, particulate emissions were found to be considerably higher with cord wood.

\section{Introduction}

Today, in both developed and developing countries, biomass remains an important energy source for heating and cooking. Wood stoves in particular are the most popular wood heating option as they are flexible and economical. Wood stoves supply heat directly to the space, unlike central boilers/furnaces which require a system of ducts to supply heat. They're easy to install, require little space, and involve little maintenance.

Currently wood stoves in the U.S. are tested for certification using EPA Method 28 "Certification and Auditing of Wood Heaters" $" 2,3$. This requires testing in 4 burn categories using dimensional lumber (cribs) of Douglas Fir. The Douglas Fir crib fuel consists of $2 \times 4$ and/or $4 \times 4$ pieces which are nailed or stapled together with the proper spacing to establish consistency of the fuel load (see Figure 1). Tests run with crib wood do not permit any round or special angular cuts to the fuel pieces and are geometrically similar to the shape of the firebox. The crib fuel must not be treated or kiln-dried and also meet the

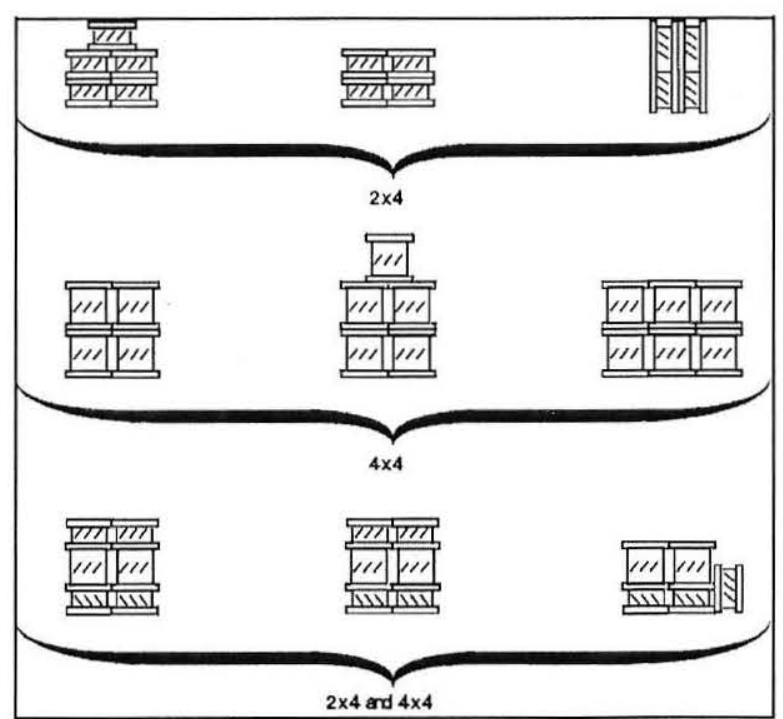

Figure 1: Test fuel crib arrangement

\footnotetext{
${ }^{1}$ U.S. EPA, Standards of Performance for New Residential Wood Heaters, New Residential Hydronic Heaters and Forced-Air Furnaces, and New Residential Masonry Heaters; Proposed Rule, Federal Register, Vol. 79, No. 22, Feb3, 2014.

2 "Method 28-Certification and Auditing of Wood Heaters", EPA, http://www.epa.gov/fem/methcollectns.htm ${ }^{3} \mathrm{http}: / / \mathrm{www}$.epa.gov/ttnemc01/promgate/m-28.pdf
} 
moisture requirement of 16 to $20 \%$ on a wet basis (19 to $25 \%$ on a dry basis). Despite the efforts to maximize consistency amongst tests and stoves, the argument still remains that cord wood (split logs) is more representative of field use and therefore real-world emissions. Under Method 28 particulate emissions are measured using either a dilution tunnel method (5G) or an in-stack method $(5 \mathrm{H})$.

In the proposed new regulations for residential wood heating devices, known as the New Source Performance Standards or "NSPS", the EPA has proposed switching the fuel used for testing devices in future years- from crib to cord wood.

The goal of this work was to compare the emission test results for cribs and cord wood in a noncatalytic stove. Crib data was provided by EPA from the EPA certification test data. In this testing particulates were measured using method $5 \mathrm{H}$ in contrast to method $5 \mathrm{G}$ used in the current work. Cord wood tests were conducted in accordance to the current draft ASTM method and considerations from Method 28.

\section{Experimental}

The stove tested for this report was an EPA certified non-catalytic stove, towards the cleaner end of the EPA certification list, i.e. $<2.0 \mathrm{~g} / \mathrm{hr}$ with crib wood. To ensure complete combustion the stove includes an insulated firebox, a system of baffles to create a longer, hotter gas flow path, and a damper to control the amount of air introduced under the fire and to the glass door "air wash". Secondary air is introduced through ports at the top of the combustion chamber.

The fuel test charge was cord wood, specifically red oak with an average moisture content of 19 to $25 \%$ on a dry basis. During testing, fuel pieces were placed in the firebox parallel to the longest firebox dimension. A full load was considered as 7 pounds per cubic foot in all tests, which is equivalent to 24 pounds of the fuel charge for the appliance. This loading was selected for consistency with the prior Method 28 crib wood data. This loading is different than is being considered in the developing ASTM method.

The test fuel was prepared by the State University of New York, College of Environmental Science and Forestry (ESF) under the direction of Dr. William Smith. The preparation involved conditioning fresh cord wood under controlled temperature and humidity conditions for time periods on the order of weeks. The moisture measurement method developed in the work at ESF was used in this work and involves averaging multiple "shell" and "core" measurements ${ }^{4}$. An example of the wood moisture data from May $20^{\text {th }}$, may be seen in Table 1

\footnotetext{
${ }^{4}$ Smith, W.B., Evaluation of Wood Fuel Moisture Measurement Accuracy for Cord wood-Fired Advanced Hydronic Heaters", Report 14-12 to NYSERDA, March 2014. Available at www.nyserda.ny.gov.
} 
Table 1: Cord wood Moisture Content Determination May $20^{\text {th }}, 2014$

\begin{tabular}{|c|c|c|c|c|c|c|c|c|c|c|}
\hline Test \# & Cat 4 & & & Name/s: & GW & & & & & \\
\hline Date: & $\begin{array}{c}\text { 5/20/2014 } \\
\text { Weight }\end{array}$ & $\begin{array}{l}\text { A- } \\
\text { end }\end{array}$ & & $\begin{array}{c}\text { Moisture } \\
\text { B- } \\
\text { center }\end{array}$ & leter: & $\begin{array}{l}\mathrm{RDM} 3 \\
\mathrm{C}- \\
\text { end }\end{array}$ & & $\begin{array}{l}\text { Predict } \\
\text { Plece } \%\end{array}$ & & \\
\hline $\begin{array}{c}\text { Piece } \\
\#\end{array}$ & Ibs & shell & Core & shell & Core & shell & Core & $A-B$ & B-C & $\begin{array}{c}\text { A-B \& } \\
\text { B-C }\end{array}$ \\
\hline 1 & 5.16 & 10.9 & 17.1 & 13.3 & 24.9 & 12.3 & 17.3 & 16.0 & 17.0 & 16.5 \\
\hline 2 & 4.89 & 13.1 & 22.1 & 18.8 & 31.9 & 13.6 & 23.1 & 20.4 & 21.9 & 21.1 \\
\hline 3 & 4.13 & 12.3 & 21.2 & 17.8 & 32.1 & 12.3 & 17.3 & 18.8 & 19.9 & 19.4 \\
\hline 4 & 5.18 & 12.1 & 24.5 & 20.4 & 33.4 & 14.4 & 21.3 & 21.0 & 22.4 & 21.7 \\
\hline 5 & 4.75 & 17.3 & 38.4 & 15.8 & 41.5 & 16.7 & 37.4 & 27.9 & 27.9 & 27.9 \\
\hline Sum & 24.1 & & & & & & Average & 20.8 & 21.8 & 21.3 \\
\hline
\end{tabular}

The fuel that was used for the tests was free of any notable decay, fungus and loose bark. The fuel charge and kindling was loaded as per the manufacturer's specifications. Kindling was weighed prior to each test; however, moisture of the kindling pieces was not recorded. The dimensions of each fuel piece were recorded for each test as well. An example from May $20^{\text {th }}$ may be seen in Figure 2.

The stove vented into a dilution tunnel hood that collected exhaust gas and mixed it with room air. The dilution ratio was controlled by a set of in-line dampers that allowed the air velocity in the dilution tunnel to be adjusted. The dilution tunnels seams and joints were sealed to prevent leakage. The velocity and pressure were measured with a pitot tube and digital pressure gauge through each test. The dilution tunnel had a diameter of 8 inches and met the specifications of ASTM E2515-10. 


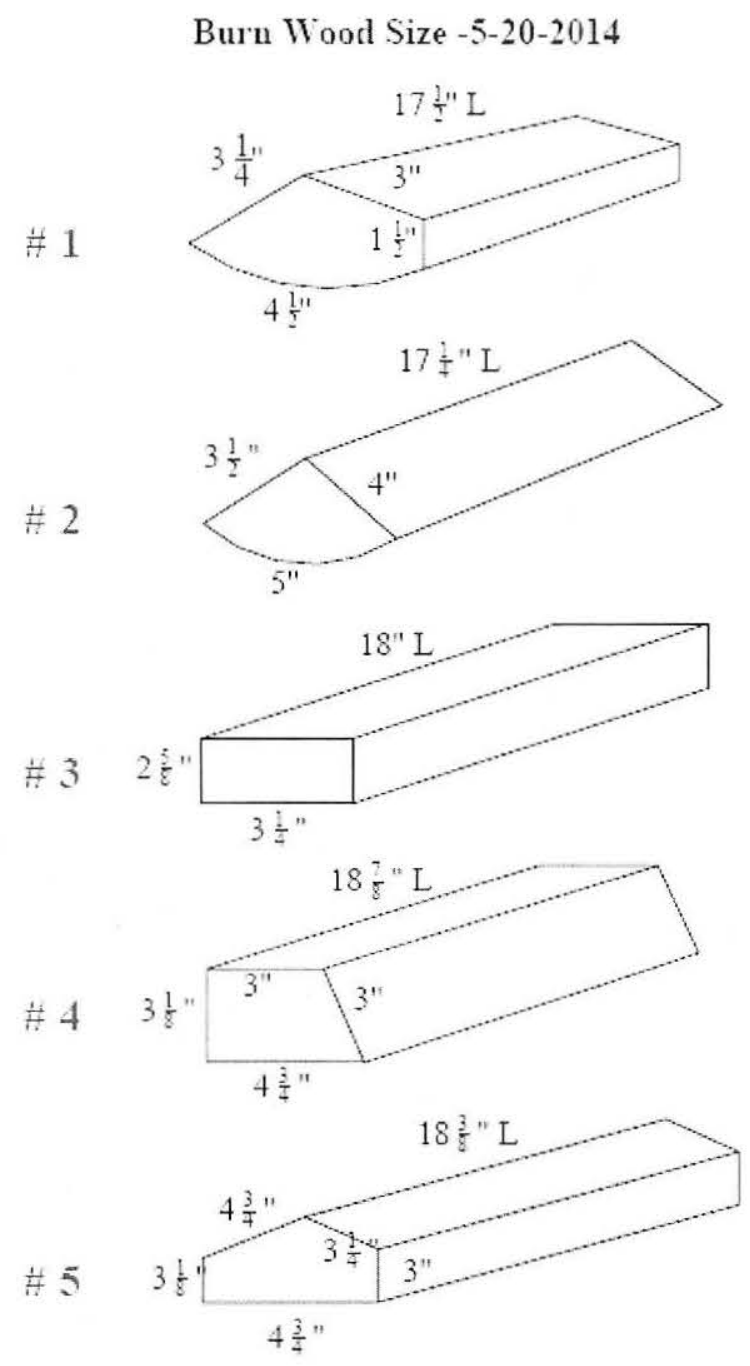

Figure 2: Fuel wood dimensions May 20th, 2014

Particulate emission measurements were made from the dilution tunnel and conducted in compliance with ASTM E2515 Standard Test Method for Determination of Particulate Matter Emissions Collected in a Dilution Tunnel. Two identical dual-filter EPA Method 5 sampling trains ${ }^{5}$ were operated simultaneously. The two sampling trains allow for quality

\footnotetext{
${ }^{5}$ Model 511 from Apex Instruments
} 
control and confirmation of the PM data collected over a period. Each sampling train consisted of two glass fiber filters in series that were each 47 millimeters in diameter.

Filters and probes were desiccated for at least 24 hours or until the weight remained constant. The components were weighed prior to the test. The probes were also rinsed with acetone before sampling and initial weights are taken to remove any PM that may have accumulated in the probe from prior tests. When loading and measuring any filters and probes, gloves and tweezers were used to eliminate excess weights attributed to dirt and oils from skin contact. Leak checks of the sampling system were performed before start of testing to ensure no leakage exists that would result in less dilution tunnel gas passing through the filters than indicated by the metering system.

Flue gas samples for analysis were taken from the dilution tunnel and directly from the flue. For sampling from the dilution tunnel, water vapor was removed using a thermoelectric cooler/drier. Gas analysis in the dilution tunnel included oxygen and carbon monoxide. Analysis of samples from the flue gas included oxygen. A decision was made to measure carbon monoxide from the dilution tunnel to allow direct calculation of the emission rate of $\mathrm{CO}$ (concentration $\times$ dilution tunnel flow rate).

Carbon monoxide was measured using a Rosemount Analytical model 880 NDIR Carbon Monoxide analyzer. Oxygen was measured in both the dilution tunnel and the hot stack via a Beckman model 755 Oxygen Analyzer. Both analyzers have a set of four ranges: 10\%, $25 \%, 50 \%$ and $100 \%$. The signals from all analyzers were logged at a 5 second intervals.

Temperatures were also measured continuously at five second increments, using TC-08 thermocouple data loggers made by Pico Technologies with type $\mathrm{K}$ thermocouples. Type $\mathrm{K}$ thermocouples are capable of measuring temperatures to within $+/-1.5^{\circ}$. The thermocouples were calibrated using an Omega CL1000 dry calibration block and were in compliance with National Institute of Standards and Technology (NIST) Monograph 175, Standard Limits of Error.

\section{Test Plan}

Three emission tests in each of the four categories of Method 28 were planned to allow evaluation of reproducibility with cord wood and provide consistent data for comparison with crib wood. However, with cord wood, the size, species, and moisture content of the test fuel can all have impacts on the test results. Therefore, for the purposes of this work, the test cord wood was guided by draft cord wood specifications and procedures under active development by ASTM. 


\section{Test Results}

Testing was successfully completed in Method 28 Categories IV, III, and II. It was not found possible to achieve the Cat. I burn rate with this fuel even when the air control damper was fully closed. In this case Method 28 provides a method for determining average emissions based on weighting the results of the other three categories in which the stove was tested. It should be noted that in the earlier certification testing with crib wood, Category I operation was also not achieved.

Table 2, below provides a summary of the tests done in each category and includes run-average burn rate. For each of the three categories achieved in testing Figures 3 to 14, below provide a comparison of the measured trends of the key parameters along with the same parameters measured during crib wood testing. The crib wood data was adopted from the submitted certification test reports.

Table 2: Outline of Tests Completed

\begin{tabular}{|c|c|c|c|}
\hline Category & Fuel & Date & Burn Rate (kg/hr) \\
\hline IV & Crib & - & 2.35 \\
\hline IV & Cord & 19-May & 2.46 \\
\hline IV & Cord & 20-May & 2.33 \\
\hline IV & Cord & 21-May & 2.57 \\
\hline III & Crib & - & 1.77 \\
\hline III & Cord & 23-May & 1.58 \\
\hline III & Cord & 28-May & 1.51 \\
\hline III & Cord & 29-May & 1.82 \\
\hline III & Cord & 30-May & 1.32 \\
\hline III & Cord & 4-June & 1.31 \\
\hline II & Crib & - & 1.12 \\
\hline II & Cord & 5-June & 1.03 \\
\hline II & Cord & 9-June & 1.13 \\
\hline II & Cord & 10-June & 1.09 \\
\hline II & Cord & 11-June & 1.16 \\
\hline I & Crib & - & 0.99 \\
\hline
\end{tabular}

1. Results reported in 2004 as part of qualification test report done by test lab.

2. As of July 1, 1990, Method 28 allowed Cat 1 to be less than 1.00 versus the original $<0.80$. [Section 5.2 of Method 28] 


\section{Cat IV}

The Cat IV trend comparisons are shown in Figures 3 to 6 below. In this case the burn rate, flue gas oxygen, and flue gas temperature trends are seen as very similar between the cord- and crib wood cases. In addition there is very good repeatability among the cord wood tests, i.e. within $3 \%$ of the average $\mathrm{g} / \mathrm{hr}$. It is important to mention the amount of fuel consumed within the first 30 minutes was 7.5, 7.5, $9.0 \mathrm{lbs}$ for the cord wood, and $9.6 \mathrm{lbs}$ for the crib wood (cord wood tests May $19^{\text {th }}$, May $20^{\text {th }}$, and May $21^{\text {st }}$, respectively). On the $19^{\text {th }}$, the door was closed immediately causing for a slower light off and lesser consumption rate within the first 30 minutes, however it was a good match to the crib wood light off from 2004. After some discussion it was decided to leave the door open longer (also recommended by the manufacturer) to prevent oxygen starvation which can cause higher emissions.

Table 3: Cat. IV Data Summary

\begin{tabular}{|c|c|c|c|c|c|c|}
\hline \multirow{2}{*}{ Cat. IV } & RUN\# & Orib & 1 & 2 & 3 & AVERAGE \\
\hline & Date & 2004 & 19-May & 20-May & 21-May & \\
\hline $\begin{array}{l}\text { Particulate } \\
\text { Emissions }\end{array}$ & Units & & & & & \\
\hline Conœentration & $\mathrm{mg} / \mathrm{m}^{\wedge} 3$ & - & 6.933 & 6.747 & 7.037 & 6.905 \\
\hline Emissions Rate & grams $/ \mathrm{hr}$ & 0.78 & 4.291 & 4.159 & 4.355 & 4.268 \\
\hline Emissions Factor & grams $/ \mathrm{kg}$ & 0.33 & 1.399 & 1.422 & 1.269 & 1.363 \\
\hline $\begin{array}{l}\text { Total Mass } \\
\text { Captured }\end{array}$ & $\mathrm{Mg}$ & 63.6 & 8.300 & 8.050 & 7.200 & 7.850 \\
\hline $\begin{array}{l}\text { Heat Output } \\
\text { (EPA Default) }\end{array}$ & $\mathrm{BTU} / \mathrm{hr}$ & & & & & \\
\hline \multicolumn{7}{|l|}{ Fuel Burn Rates } \\
\hline \multirow{2}{*}{$\begin{array}{c}\text { Average Burn } \\
\text { Rate }\end{array}$} & $\mathrm{kg} / \mathrm{hr}$ (dry) & 2.35 & 2.46 & 2.33 & 2.57 & 2.45 \\
\hline & $\mathrm{lb} / \mathrm{hr}$ (dry) & 5.18 & 5.43 & 5.13 & 5.67 & 5.41 \\
\hline \multicolumn{7}{|l|}{$\begin{array}{l}\text { Fuel Moisture } \\
\text { Content }\end{array}$} \\
\hline $\begin{array}{l}\text { Kndling (wet } \\
\text { basis) }\end{array}$ & $\%$ & 14.966 & N/A & N/A & N/A & N/A \\
\hline $\begin{array}{l}\text { Pretest Fuel (wet } \\
\text { basis) }\end{array}$ & $\%$ & 18.897 & 20.1 & 19.9 & 21.2 & 20.4 \\
\hline $\begin{array}{c}\text { Test Fuel (wet } \\
\text { basis) }\end{array}$ & $\%$ & 17.519 & 20.6 & 21.3 & 25.7 & 22.53 \\
\hline
\end{tabular}




\begin{tabular}{|c|c|c|c|c|c|c|}
\hline Air to Fuel Ratio & & N/A & N/A & N/A & N/A & N/A \\
\hline \multicolumn{7}{|l|}{$\begin{array}{c}\text { Average Stack } \\
\text { Gas }\end{array}$} \\
\hline Avg 002 & $\%$ & 7.48 & N/A & N/A & N/A & N/A \\
\hline Avg $\mathrm{O} 2$ & $\%$ & N/A & 12.8 & 12.9 & 11.43 & 12.38 \\
\hline Avg $\infty$ & $\%$ & 0.58 & 0.03 & 0.03 & 0.03 & 0.03 \\
\hline Avg moisture & $\%$ & 6.35 & 10 & 10 & 10 & 10 \\
\hline \multicolumn{7}{|l|}{$\begin{array}{l}\text { Average Stadk } \\
\text { Gas Emissions }\end{array}$} \\
\hline \multirow[t]{2}{*}{$\infty$} & $\mathrm{g} / \mathrm{kg}$ & 74.13 & & & & \\
\hline & $\mathrm{g} / \mathrm{hr}$ & 174.14 & & & & \\
\hline \multicolumn{7}{|l|}{$\begin{array}{c}\text { Average } \\
\text { Temperatures }\end{array}$} \\
\hline Stack Gas & ${ }^{\circ} \mathrm{F}$ & 403 & 437 & 420 & 415 & 424 \\
\hline Frebox & ${ }^{\circ} \mathrm{F}$ & 984 & N/A & N/A & N/A & N/A \\
\hline Secondary & ${ }^{\circ} \mathrm{F}$ & 1093 & N/A & N/A & N/A & N/A \\
\hline $\begin{array}{l}\text { Catalytic } \\
\text { Combustor }\end{array}$ & ${ }^{\circ} \mathrm{F}$ & $\mathrm{N} / \mathrm{A}$ & N/A & N/A & N/A & $\mathrm{N} / \mathrm{A}$ \\
\hline Top & ${ }^{\circ} \mathrm{F}$ & 311 & 436 & 420 & 459 & 438 \\
\hline Left Sde & ${ }^{\circ} \mathrm{F}$ & 404 & 548 & 555 & 604 & 569 \\
\hline Back & ${ }^{\circ} \mathrm{F}$ & 232 & 86 & 86 & 86 & 86 \\
\hline Right Sde & ${ }^{\circ} \mathrm{F}$ & 424 & 378 & 363 & 410 & 384 \\
\hline Bottom & ${ }^{\circ} \mathrm{F}$ & 352 & N/A & N/A & N/A & N/A \\
\hline $\begin{array}{c}\text { Temperature } \\
\text { Change }\end{array}$ & ${ }^{\circ} \mathrm{F}$ & -74 & -86.7 & -18.4 & -12.9 & -39.3 \\
\hline \multicolumn{7}{|l|}{$\begin{array}{l}\text { Test Chamber } \\
\text { Environment }\end{array}$} \\
\hline $\begin{array}{l}\text { Average } \\
\text { Barometer }\end{array}$ & in. $\mathrm{Hg}$ & 30.17 & 29.97 & 29.91 & 29.88 & 29.92 \\
\hline $\begin{array}{c}\text { Average } \\
\text { Temperature }\end{array}$ & ${ }^{\circ} \mathrm{F}$ & 79 & 73 & 75 & 67 & 72 \\
\hline $\begin{array}{l}\text { Ambient } \\
\text { Moisture }\end{array}$ & $\% \mathrm{H} 2 \mathrm{O}$ & 1.45 & & & & \\
\hline $\begin{array}{l}\text { Relative } \\
\text { Humidity }\end{array}$ & $\% \mathrm{RH}$ & 33.5 & 33.8 & 24.4 & 42 & 33.4 \\
\hline Air Velocity & $\mathrm{m} / \mathrm{sec}$ & 0 & & & & \\
\hline $\begin{array}{l}\text { Fuel Weight and } \\
\text { Burn Time }\end{array}$ & & & & & & \\
\hline
\end{tabular}




\begin{tabular}{|c|c|c|c|c|c|c|}
$\begin{array}{c}\text { Density (dry } \\
\text { basis) }\end{array}$ & $\mathrm{gm} / \mathrm{cm}^{\wedge} 3$ & N/A & N/A & N/A & N/A & N/A \\
\hline Coal Bed Weight & Lbs & 4.9 & 6.3 & 5.6 & 5.1 & 5.7 \\
\hline $\begin{array}{c}\text { Pre Test Fuel } \\
\text { (inc. kindling) }\end{array}$ & Lbs & 47.1 & 28.8 & 22.5 & 28.3 & 26.5 \\
\hline Test Fuel & Lbs & 22.5 & 24.4 & 23.9 & 24.2 & 24.2 \\
\hline Burn Time & Min & 215 & 213.92 & 219.92 & 190.42 & 208.1 \\
\hline
\end{tabular}

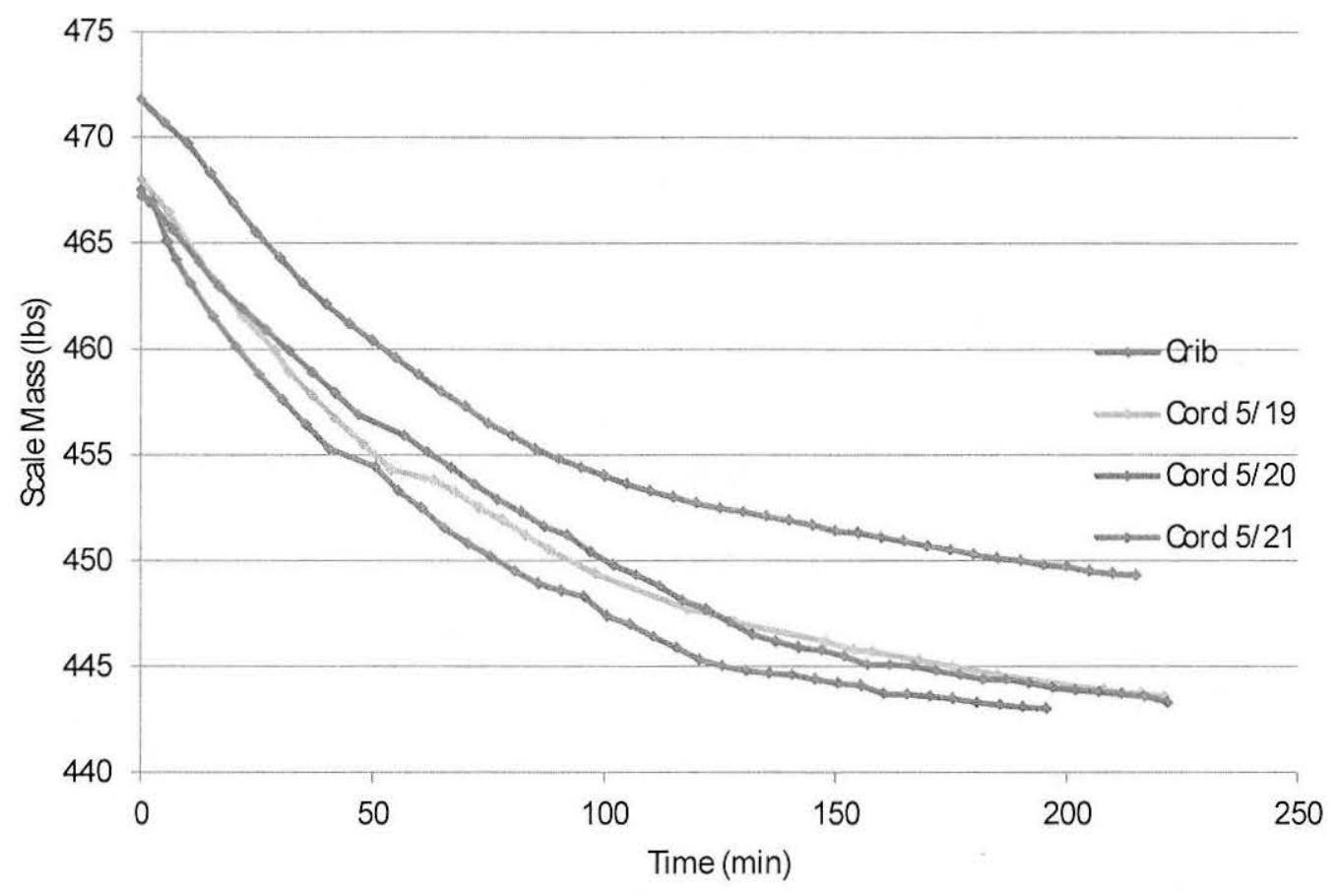

Figure 3: Cat. IV fuel consumption trends 


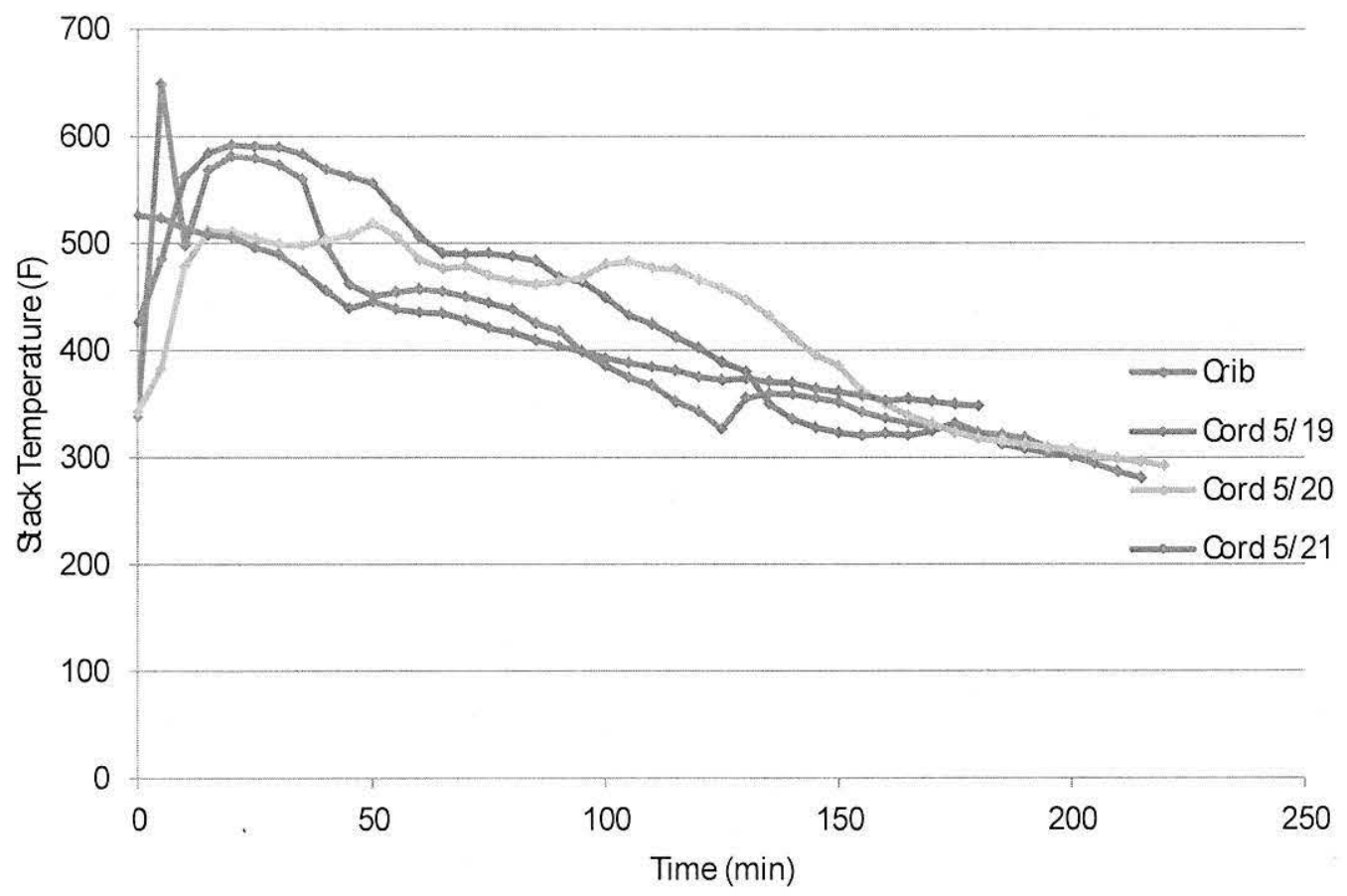

Figure 4: Cat. IV stack temperature frends

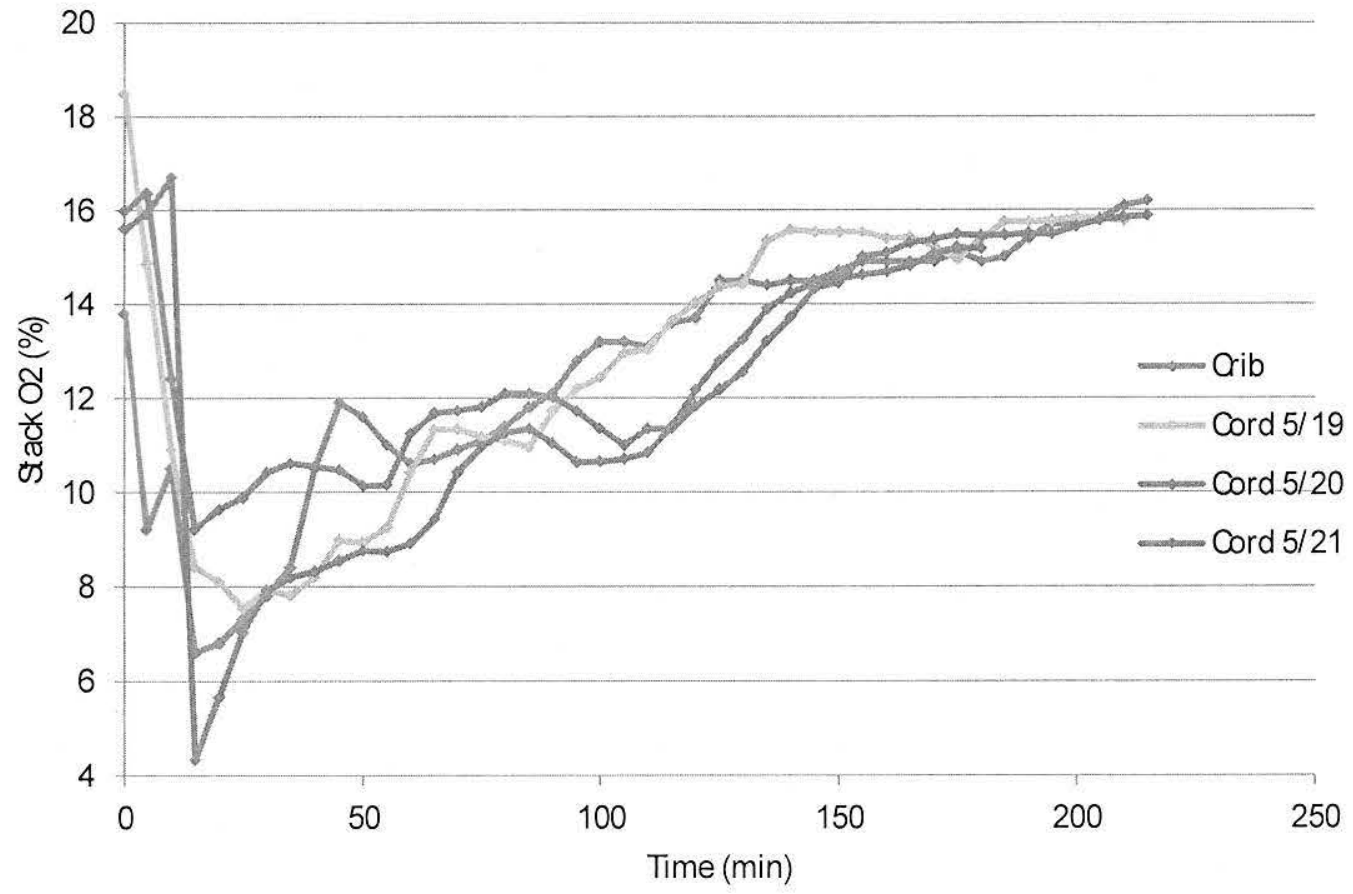

Figure 5: Cat. IV stack oxygen trends 


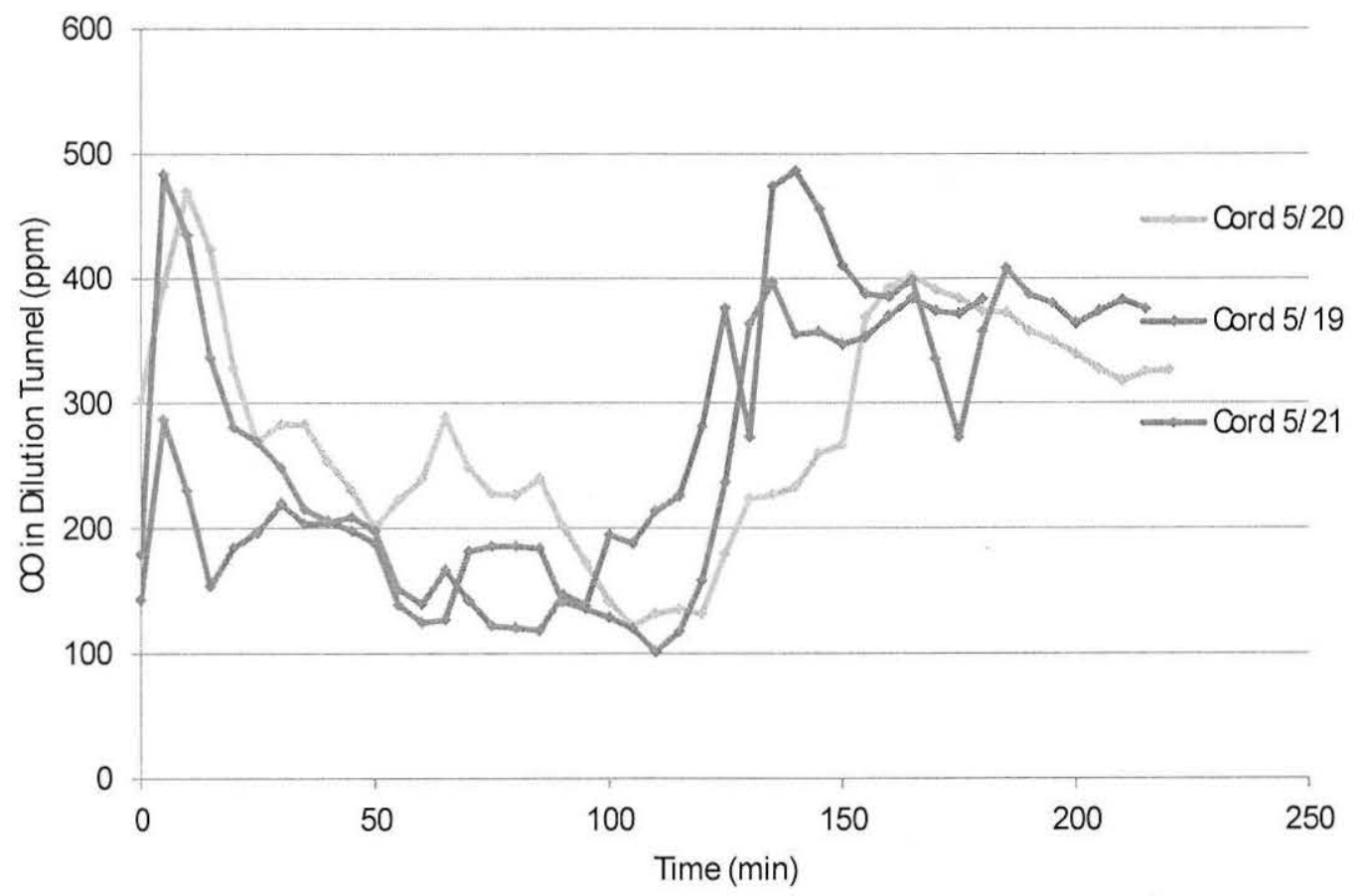

Figure 6: Cat. IV carbon monoxide trends 


\section{Cat III}

The Cat III trend comparisons are shown in Figures 7 to 10 below. Again, in this case the burn rate, flue gas oxygen, and flue gas temperature trends are seen as very similar between the cordand crib wood cases. However, the cord wood was wetter $(22.0 \%)$ versus the 2004 crib wood case $(17.8 \%)$. The repeatability in the flue gas oxygen and temperature between the individual cord wood tests is not as clear as with the Cat IV tests. The fuel consumed within the first 30 minutes for the crib, May $23^{\text {rd }}$, May $28^{\text {th }}$, May $29^{\text {th }}$, May $30^{\text {th }}$, and June $4^{\text {th }}$ tests was $5.6,5.7,7.9$, 7.6, 7.6, and $6.3 \mathrm{lbs}$, respectively. For these tests the door was left partially open for a full five minutes after the fuel charge was added.

Table 4: Cat. III Data Summary

\begin{tabular}{|c|c|c|c|c|c|c|c|c|}
\hline \multirow{2}{*}{ Cat. III } & RUN\# & arib & 1 & 2 & 3 & 4 & 5 & AVERAGE \\
\hline & Date & 2004 & 23-May & 28-May & 29-May & 30-May & 4-lun & \\
\hline $\begin{array}{l}\text { Particulate } \\
\text { Enissions }\end{array}$ & Units & & & & & . & & \\
\hline Concentration & $\mathrm{mg} / \mathrm{m}^{\wedge} 3$ & - & 9.973 & 13.403 & 26.009 & 14.166 & 25.562 & 17.822 \\
\hline Emissions Rate & grams/hr & 1.1 & 6.461 & 8.748 & 17.402 & 9.398 & 16.605 & 11.723 \\
\hline $\begin{array}{l}\text { Emissions } \\
\text { Factor }\end{array}$ & grams/kg & 0.62 & 3.185 & 4.555 & 7.301 & 5.495 & 9.860 & 6.079 \\
\hline $\begin{array}{c}\text { Total Mass } \\
\text { Captured }\end{array}$ & $\mathrm{mg}$ & 127.8 & 17.450 & 24.600 & 40.000 & 30.500 & 53.600 & 33.230 \\
\hline $\begin{array}{l}\text { Heat Output } \\
\text { (BPA Default) }\end{array}$ & $\mathrm{BTU} / \mathrm{hr}$ & & & & & & & \\
\hline \multicolumn{9}{|l|}{$\begin{array}{l}\text { Fuel Burn } \\
\text { Rates }\end{array}$} \\
\hline \multirow{2}{*}{$\begin{array}{c}\text { Average Burn } \\
\text { Rate }\end{array}$} & $\begin{array}{l}\mathrm{kg} / \mathrm{hr} \\
\text { (dry) }\end{array}$ & 1.77 & 1.58 & 1.51 & 1.82 & 1.32 & 1.31 & 1.51 \\
\hline & $\begin{array}{l}\mathrm{lb} / \mathrm{hr} \\
\text { (dry) }\end{array}$ & 3.9 & 3.49 & 3.33 & 4.01 & 2.92 & 2.89 & 3.33 \\
\hline \multicolumn{9}{|l|}{$\begin{array}{l}\text { Fuel Moisture } \\
\text { Content }\end{array}$} \\
\hline $\begin{array}{l}\text { Kndling (wet } \\
\text { basis) }\end{array}$ & $\%$ & 13.917 & NA & NA & NA & NA & NA & \\
\hline $\begin{array}{l}\text { Pretest Fuel } \\
\text { (wet basis) }\end{array}$ & $\%$ & 18.8 & 19 & 18.38 & 17.51 & 18.7 & 14.6 & 17.638 \\
\hline $\begin{array}{c}\text { Test Fuel (wet } \\
\text { basis) }\end{array}$ & $\%$ & 17.8 & 22.1 & 21.5 & 21.58 & 22.58 & 22.2 & 21.992 \\
\hline & & & & & & & & \\
\hline
\end{tabular}




\begin{tabular}{|c|c|c|c|c|c|c|c|c|}
\hline $\begin{array}{l}\text { Air to Fuel } \\
\text { Ratio }\end{array}$ & & N/A & NA & NA & NA & NA & NA & NA \\
\hline \multicolumn{9}{|l|}{$\begin{array}{c}\text { Average Stack } \\
\text { Gas }\end{array}$} \\
\hline Avg 002 & $\%$ & 6.76 & N/A & NA & NA & NA & NA & NA \\
\hline Avg $\mathrm{O} 2$ & $\%$ & N/A & 13.2 & 12 & 12.34 & 12.59 & 10.8 & 12.186 \\
\hline Avg $\infty$ & $\%$ & 0.87 & 0.04 & 0.03 & 0.04 & 0.04 & 0.03 & 0.0369568 \\
\hline Avg moisture & $\%$ & 5.92 & 10 & 10 & 10 & 10 & 10 & 10 \\
\hline \multicolumn{9}{|l|}{$\begin{array}{l}\text { Average Stack } \\
\text { Gas Emissions }\end{array}$} \\
\hline \multirow[t]{2}{*}{$\infty$} & $\mathrm{g} / \mathrm{kg}$ & 117.02 & & & & & & \\
\hline & $\mathrm{g} / \mathrm{hr}$ & 207.59 & & & & & & \\
\hline & & & & & & & & \\
\hline \multicolumn{9}{|l|}{$\begin{array}{c}\text { Average } \\
\text { Temperatures }\end{array}$} \\
\hline Stack Gas & ${ }^{\circ} \mathrm{F}$ & 335 & 309 & 281 & 298 & 240 & 248 & 275.2 \\
\hline Firebox & ${ }^{\circ} \mathrm{F}$ & 725 & NA & NA & NA & $\mathrm{NA}$ & NA & \\
\hline Secondary & ${ }^{\circ} \mathrm{F}$ & 953 & NA & NA & NA & NA & NA & \\
\hline $\begin{array}{l}\text { Catalytic } \\
\text { Combustor }\end{array}$ & ${ }^{\circ} \mathrm{F}$ & N/A & NA & NA & NA & NA & NA & \\
\hline Top & ${ }^{\circ} \mathrm{F}$ & 334 & 346 & 336 & 333 & 275 & 295 & 317 \\
\hline Left Sde & ${ }^{\circ} \mathrm{F}$ & 370 & 450 & 444 & 449 & 417 & 417 & 435.4 \\
\hline Back & ${ }^{\circ} \mathrm{F}$ & 313 & 88 & 82 & 81 & 86 & 84 & 84.2 \\
\hline Right Sde & ${ }^{\circ} \mathrm{F}$ & 376 & 330 & 355 & 352 & 318 & 331 & 337.2 \\
\hline Bottom & ${ }^{\circ} \mathrm{F}$ & 325 & NA & NA & NA & NA & N/A & \\
\hline $\begin{array}{c}\text { Temperature } \\
\text { Change }\end{array}$ & ${ }^{\circ} \mathrm{F}$ & -67.7 & -99 & -156.9 & -69.59 & -134.28 & -110.67 & -114.088 \\
\hline \multicolumn{9}{|l|}{$\begin{array}{l}\text { Test Chamber } \\
\text { Environment }\end{array}$} \\
\hline $\begin{array}{l}\text { Average } \\
\text { Barometer }\end{array}$ & in. $\mathrm{Hg}$ & 30.21 & 29.8 & 29.92 & 30.13 & 29.96 & 29.7 & 29.902 \\
\hline $\begin{array}{c}\text { Average } \\
\text { Temperature }\end{array}$ & ${ }^{\circ} \mathrm{F}$ & 79 & 72 & 71 & 66 & 72 & 76 & 71.4 \\
\hline $\begin{array}{l}\text { Ambient } \\
\text { Moisture }\end{array}$ & $\% \mathrm{H} 2 \mathrm{O}$ & 1.2 & & & & & & \\
\hline $\begin{array}{l}\text { Relative } \\
\text { Humidity }\end{array}$ & $\%$ RH & 33.5 & 99.2 & 91.2 & 59.3 & 58.5 & 74.6 & 76.56 \\
\hline Air Velocity & $\mathrm{m} / \mathrm{sec}$ & 0 & & & & & & \\
\hline & & & & & & & & \\
\hline $\begin{array}{l}\text { Fuel Weight } \\
\text { and Burn Time }\end{array}$ & & & & & & & & \\
\hline
\end{tabular}




\begin{tabular}{|c|c|c|c|c|c|c|c|c|}
$\begin{array}{c}\text { Density (dry } \\
\text { basis) }\end{array}$ & $\mathrm{gm} / \mathrm{cm}^{\wedge} 3$ & N/A & NA & NA & NA & NA & NA & NA \\
\hline $\begin{array}{c}\text { Coal Bed } \\
\text { Weight }\end{array}$ & lbs & 5.3 & 5 & 5.3 & 6 & 5.7 & 6.1 & 5.62 \\
\hline $\begin{array}{c}\text { Pre Test Fuel } \\
\text { (inc. kindling) }\end{array}$ & Ibs & 62.6 & 26.4 & 26 & 26.9 & 28.6 & 28.1 & 27.20 \\
\hline Test Fuel & Ibs & 23 & 24.5 & 24 & 24.2 & 25 & 24.7 & 24.48 \\
\hline Burn Time & $\mathrm{min}$ & 290 & 328.00 & 339.17 & 283.75 & 398.15 & 399.02 & 349.62 \\
\hline
\end{tabular}

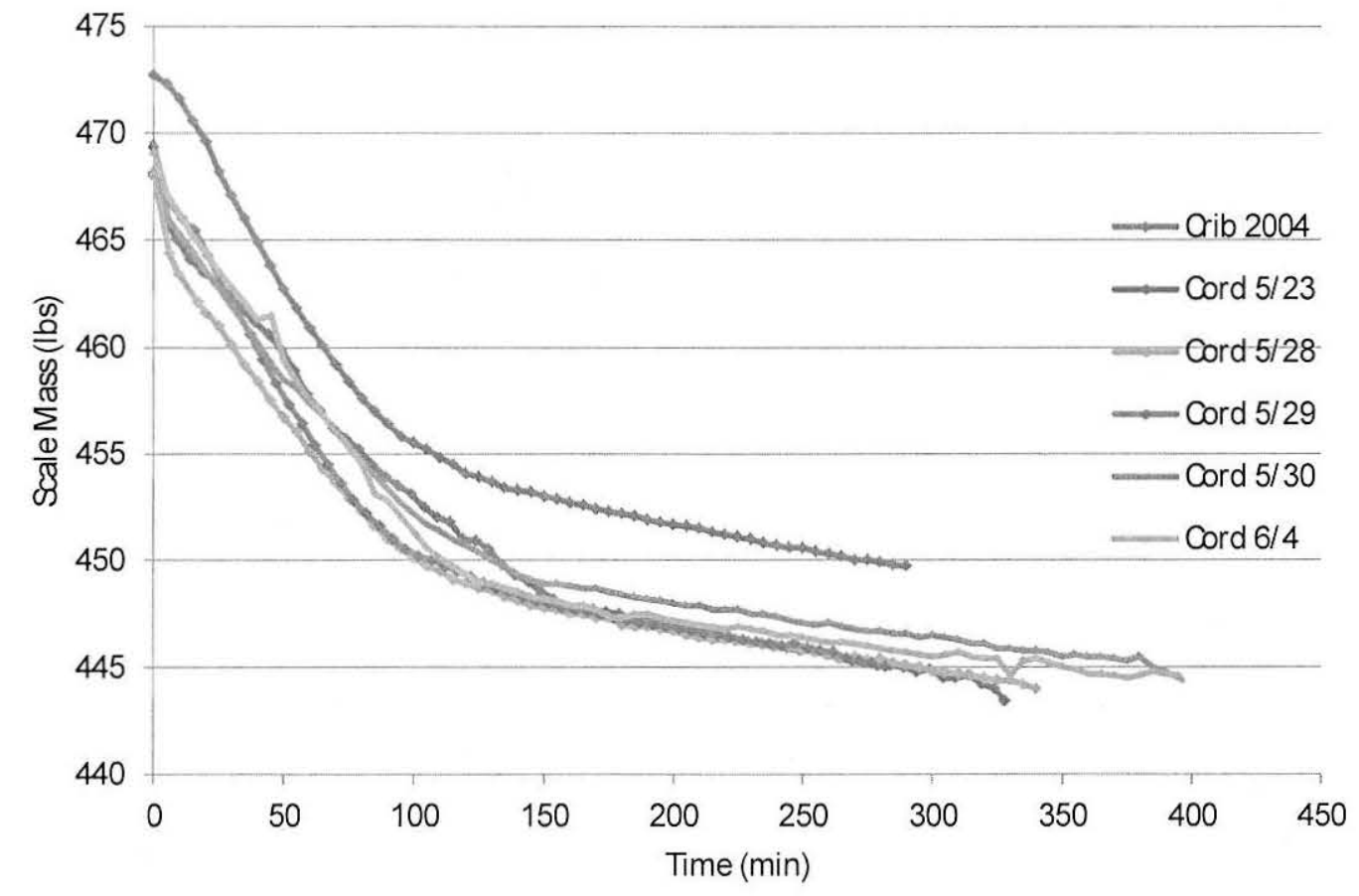

Figure 7: Cat. III fuel consumption trends 


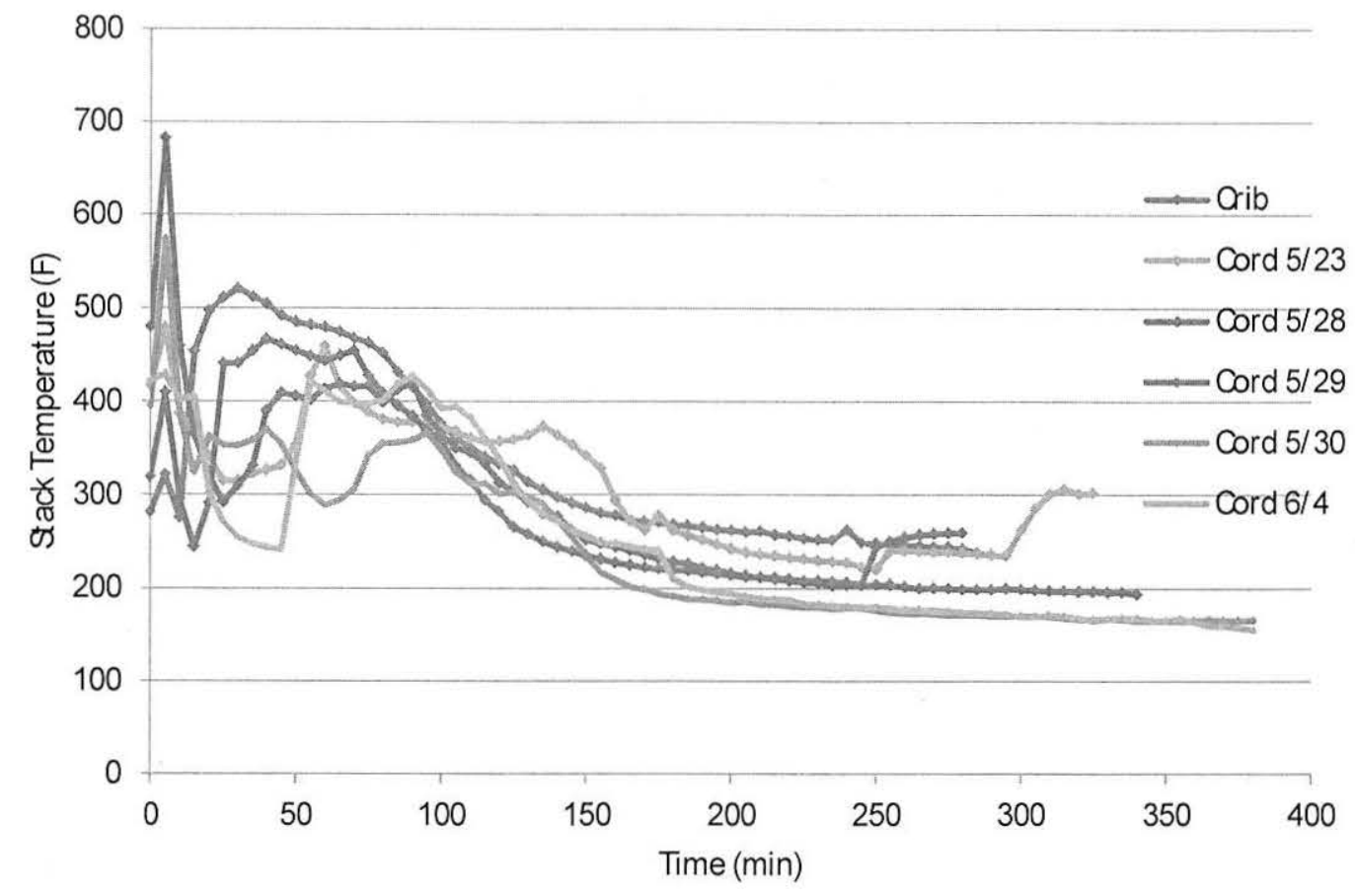

Figure 8: Cat. III stack temperature trends

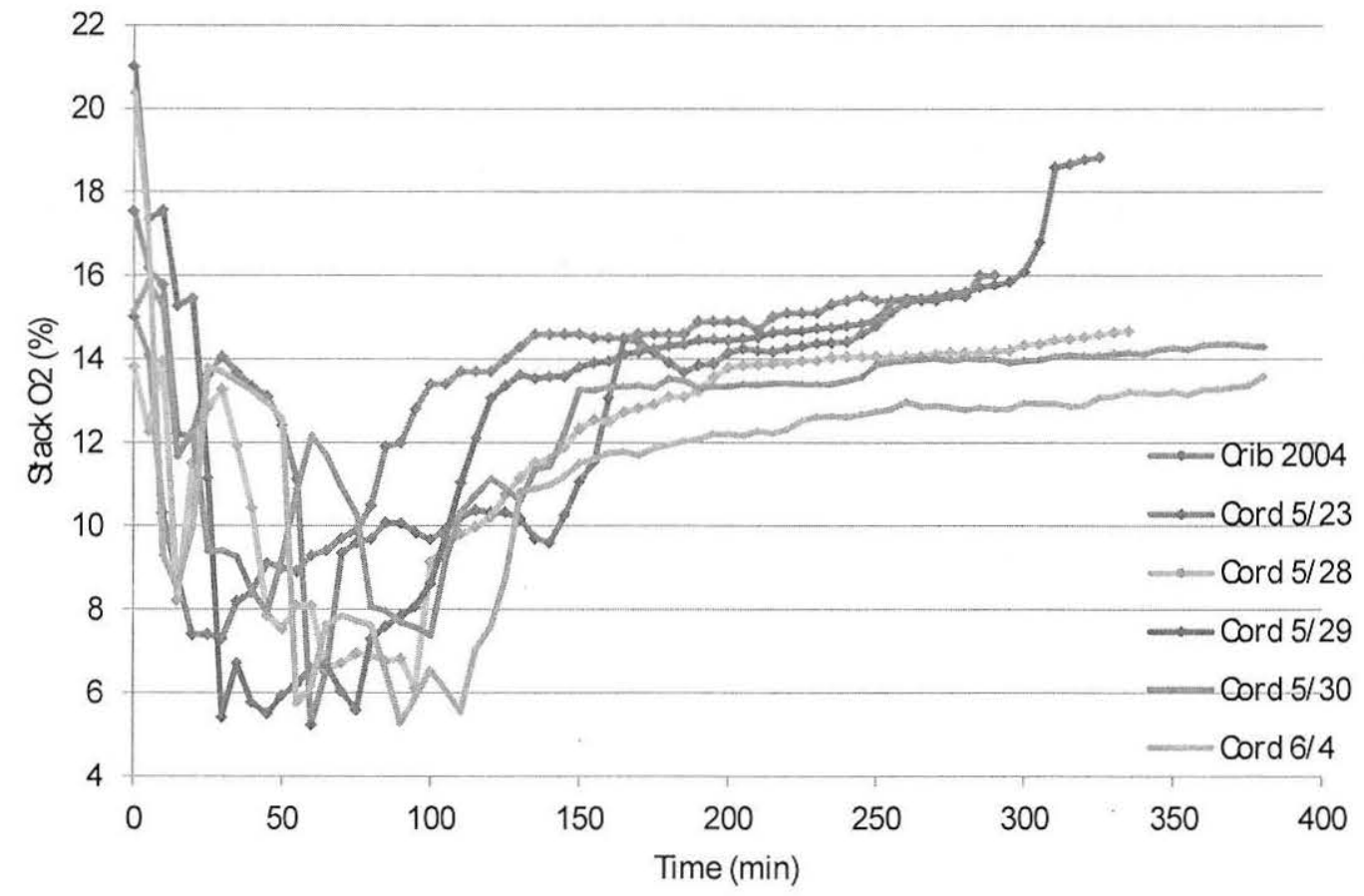

Figure 9: Cat. III stack oxygen trends 


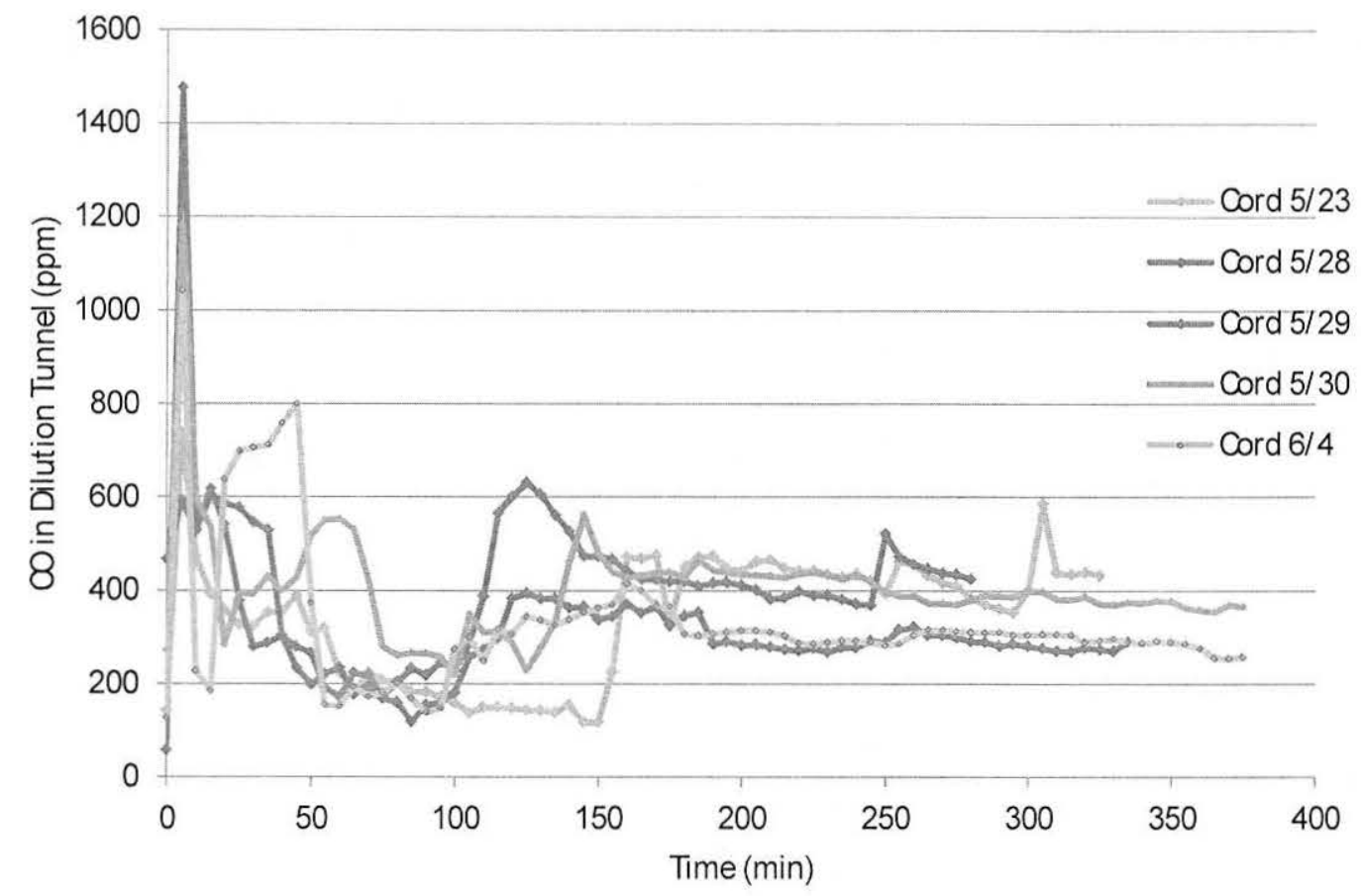

Figure 10: Cat. III carbon monoxide trends 


\section{Cat II}

The Cat. II trend comparisons are shown in Figures 11 to 14 below. In this case the burn rate, flue gas oxygen, and flue gas temperature trends are seen as very similar between the cord- and crib wood cases. In addition there is very good repeatability among the cord wood tests, i.e., within $10 \%$ of the average $\mathrm{g} / \mathrm{hr}$. The cord wood moisture content $(19.6 \%)$ was somewhat higher than the crib wood case $(17.1 \%)$. The consumption of fuel for the first 30 minutes for the crib, June $5^{\text {th }}$, June $9^{\text {th }}$, June $10^{\text {th }}$, and June $11^{\text {th }}$ tests was $3.7,4.5,3.9,4.0$, and 3.2 , respectively. For the Cat. II tests, the door was closed completely within two minutes of loading the fuel charge to prevent a high initial consumption rate causing for an overall higher consumption rate and higher category.

Table 5: Cat. II Data Summary

\begin{tabular}{|c|c|c|c|c|c|c|c|}
\hline \multirow{2}{*}{ Cat. II } & RUN\# & Orib & 1 & 2 & 3 & 4 & AVERAGE \\
\hline & Date & 2004 & 5-lun & 9-lun & 10-lun & 11-lun & \\
\hline $\begin{array}{c}\text { Particulate } \\
\text { Emissions }\end{array}$ & Units & & & & & & \\
\hline Concentration & $\mathrm{mg} / \mathrm{m}^{\wedge} 3$ & - & 54.497 & 72.424 & 115.583 & 128.783 & 92.822 \\
\hline Emissions Rate & grams/hr & 2.230 & 36.012 & 48.088 & 34.756 & 41.123 & 39.995 \\
\hline $\begin{array}{l}\text { Emissions } \\
\text { Factor }\end{array}$ & grams $/ \mathrm{kg}$ & 2.000 & 27.884 & 34.697 & 31.174 & 27.677 & 30.358 \\
\hline $\begin{array}{l}\text { Total Mass } \\
\text { Captured }\end{array}$ & $\mathrm{mg}$ & 638.600 & 142.200 & 181.600 & 296.650 & 312.750 & 233.300 \\
\hline $\begin{array}{l}\text { Heat Output } \\
\text { (BA Default) }\end{array}$ & BTU/hr & & & & & & \\
\hline & & & & & & & \\
\hline \multicolumn{8}{|l|}{$\begin{array}{c}\text { Fuel Burn } \\
\text { Rates }\end{array}$} \\
\hline \multirow{2}{*}{$\begin{array}{l}\text { Average Burn } \\
\text { Rate }\end{array}$} & $\begin{array}{l}\mathrm{kg} / \mathrm{hr} \\
\text { (dry) }\end{array}$ & 1.12 & 1.03 & 1.13 & 1.09 & 1.16 & 1.10 \\
\hline & $\begin{array}{l}\mathrm{Ib} / \mathrm{hr} \\
\text { (dry) }\end{array}$ & 2.47 & 2.28 & 2.48 & 2.39 & 2.57 & 2.43 \\
\hline \multicolumn{8}{|l|}{$\begin{array}{l}\text { Fuel Moisture } \\
\text { Content }\end{array}$} \\
\hline $\begin{array}{l}\text { Kndling (wet } \\
\text { basis) }\end{array}$ & $\%$ & 13.119 & NA & NA & NA & NA & NA \\
\hline $\begin{array}{c}\text { Pretest Fuel } \\
\text { (wet basis) }\end{array}$ & $\%$ & 19.041 & 18.1 & 15.9 & 14.9 & 14.7 & 15.9 \\
\hline $\begin{array}{c}\text { Test Fuel (wet } \\
\text { basis) }\end{array}$ & $\%$ & 17.118 & 20 & 18.9 & 18.1 & 21.2 & 19.55 \\
\hline $\begin{array}{l}\text { Air to Fuel } \\
\text { Ratio }\end{array}$ & & & NA & NA & NA & NA & NA \\
\hline $\begin{array}{c}\text { Average Sack } \\
\text { Gas }\end{array}$ & & & & & & & \\
\hline
\end{tabular}




\begin{tabular}{|c|c|c|c|c|c|c|c|}
\hline Avg $œ 2$ & $\%$ & 5.87 & NA & NA & NA & NA & NA \\
\hline Avg O2 & $\%$ & $\mathrm{~N} / \mathrm{A}$ & 13.1 & 13.4 & 11.5 & 11.6 & 12.4 \\
\hline Avg $\subseteq$ & $\%$ & 1.11 & 0.03 & 0.04 & 0.09 & 0.08 & 0.060396 \\
\hline Avg moisture & $\%$ & 5.04 & 10 & 10 & 10 & 10 & 10 \\
\hline \multicolumn{8}{|l|}{$\begin{array}{l}\text { Average Stack } \\
\text { Gas Emissions }\end{array}$} \\
\hline \multirow[t]{2}{*}{$\infty$} & $\mathrm{g} / \mathrm{kg}$ & 160.7 & & & & & \\
\hline & $\mathrm{g} / \mathrm{hr}$ & 179.99 & & & & & \\
\hline & & & & & & & \\
\hline \multicolumn{8}{|l|}{$\begin{array}{c}\text { Average } \\
\text { Temperatures }\end{array}$} \\
\hline Stack Gas & ${ }^{\circ} \mathrm{F}$ & 238 & 173 & 174 & 164 & 175 & 171.5 \\
\hline Firebox & ${ }^{\circ} \mathrm{F}$ & 607 & NA & NA & NA & NA & NA \\
\hline Secondary & ${ }^{\circ} \mathrm{F}$ & 692 & NA & NA & NA & NA & NA \\
\hline $\begin{array}{l}\text { Catalytic } \\
\text { Combustor }\end{array}$ & ${ }^{\circ} \mathrm{F}$ & N/A & N/A & NA & NA & NA & NA \\
\hline Top & ${ }^{\circ} \mathrm{F}$ & 268 & 216 & 205 & 219 & 207 & 211.75 \\
\hline Left Sde & ${ }^{\circ} \mathrm{F}$ & 306 & 357 & 330 & 333 & 347 & 341.75 \\
\hline Back & ${ }^{\circ} \mathrm{F}$ & 251 & 88 & 88 & 92 & 92 & 90 \\
\hline Right Sde & ${ }^{\circ} \mathrm{F}$ & 316 & 271 & 295 & 279 & 288 & 283.25 \\
\hline Bottom & ${ }^{\circ} \mathrm{F}$ & 179 & NA & NA & NA & NA & NA \\
\hline $\begin{array}{c}\text { Temperature } \\
\text { Change }\end{array}$ & ${ }^{\circ} \mathrm{F}$ & -77 & -167 & -204.5 & -219.2 & -142.5 & -183.3 \\
\hline \multicolumn{8}{|l|}{$\begin{array}{l}\text { Test Chamber } \\
\text { Environment }\end{array}$} \\
\hline $\begin{array}{l}\text { Average } \\
\text { Barometer }\end{array}$ & in. $\mathrm{Hg}$ & 30.08 & 29.55 & 29.87 & 29.86 & 30.01 & 29.8225 \\
\hline $\begin{array}{c}\text { Average } \\
\text { Temperature }\end{array}$ & ${ }^{\circ} \mathrm{F}$ & 75 & 69 & 69 & 73 & 73 & 71 \\
\hline $\begin{array}{l}\text { Ambient } \\
\text { Moisture }\end{array}$ & $\% \mathrm{H}_{2} \mathrm{O}$ & 1.2 & & & & & \\
\hline $\begin{array}{l}\text { Relative } \\
\text { Humidity }\end{array}$ & $\%$ PH & 29.5 & 93.8 & 91.7 & 88.35 & 71.95 & 86.45 \\
\hline Air Velocity & $\mathrm{m} / \mathrm{sec}$ & 0 & & & & & \\
\hline \multicolumn{8}{|l|}{$\begin{array}{l}\text { Fuel Weight } \\
\text { and Burn Time }\end{array}$} \\
\hline $\begin{array}{l}\text { Density (dry } \\
\text { basis) }\end{array}$ & $\mathrm{gm} / \mathrm{cm}^{\wedge} 3$ & $\mathrm{~N} / \mathrm{A}$ & NA & NA & NA & NA & NA \\
\hline $\begin{array}{l}\text { Coal Bed } \\
\text { Weight }\end{array}$ & Ibs & 5.6 & 5.9 & 6.7 & 5.6 & 5.3 & 5.875 \\
\hline $\begin{array}{l}\text { Pre Test Fuel } \\
\text { (inc. kindling) }\end{array}$ & Ibs & 64.2 & 27.1 & 28.2 & 28.4 & 27.9 & 27.9 \\
\hline Test Fuel & Ibs & 22.6 & 23.9 & 24 & 24.9 & 25.8 & 24.65 \\
\hline Burn Time & $\min$ & 455.00 & 503.17 & 470.75 & 510.92 & 475.00 & 489.9583 \\
\hline
\end{tabular}




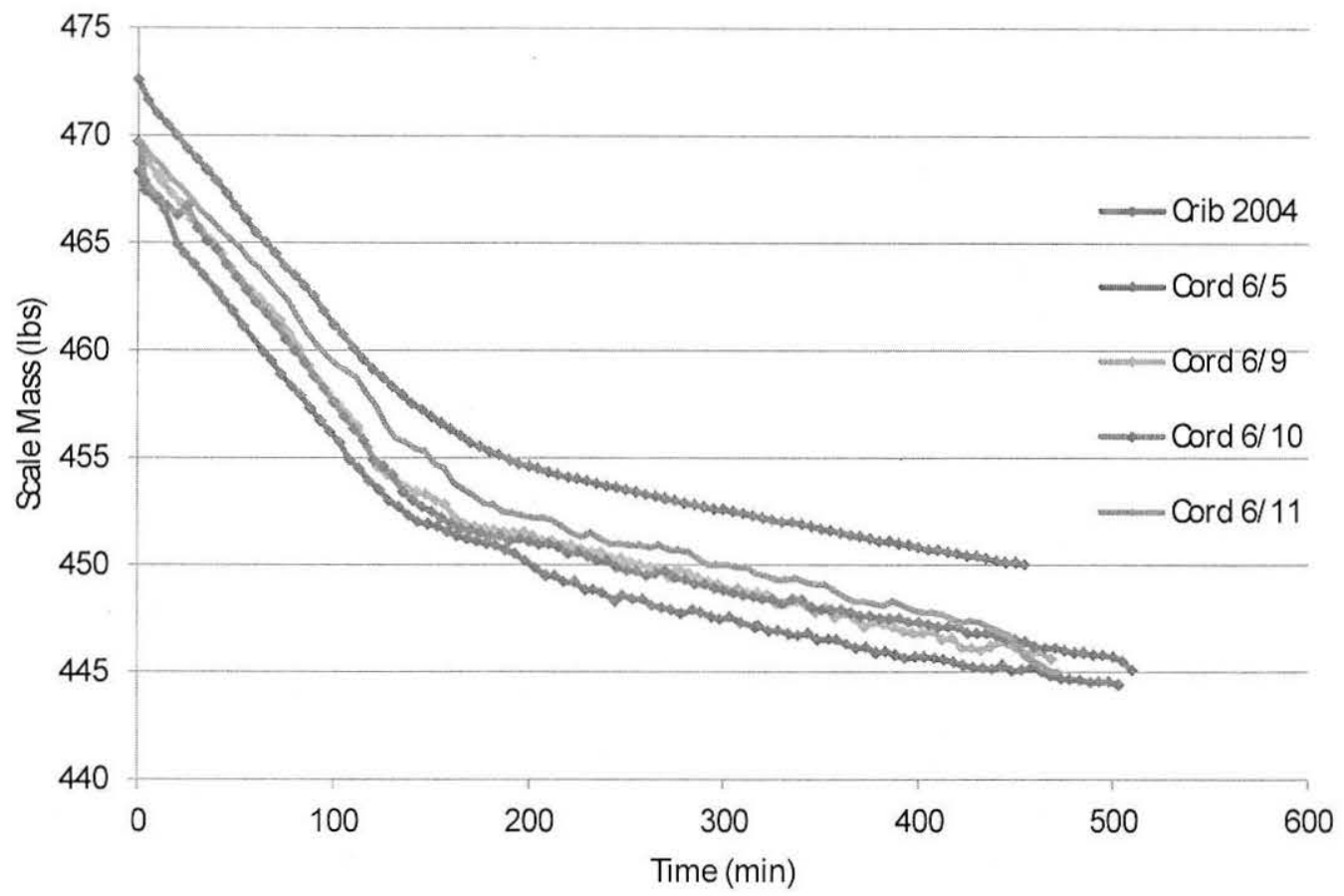

Figure I1: Cat. II fuel consumption trends

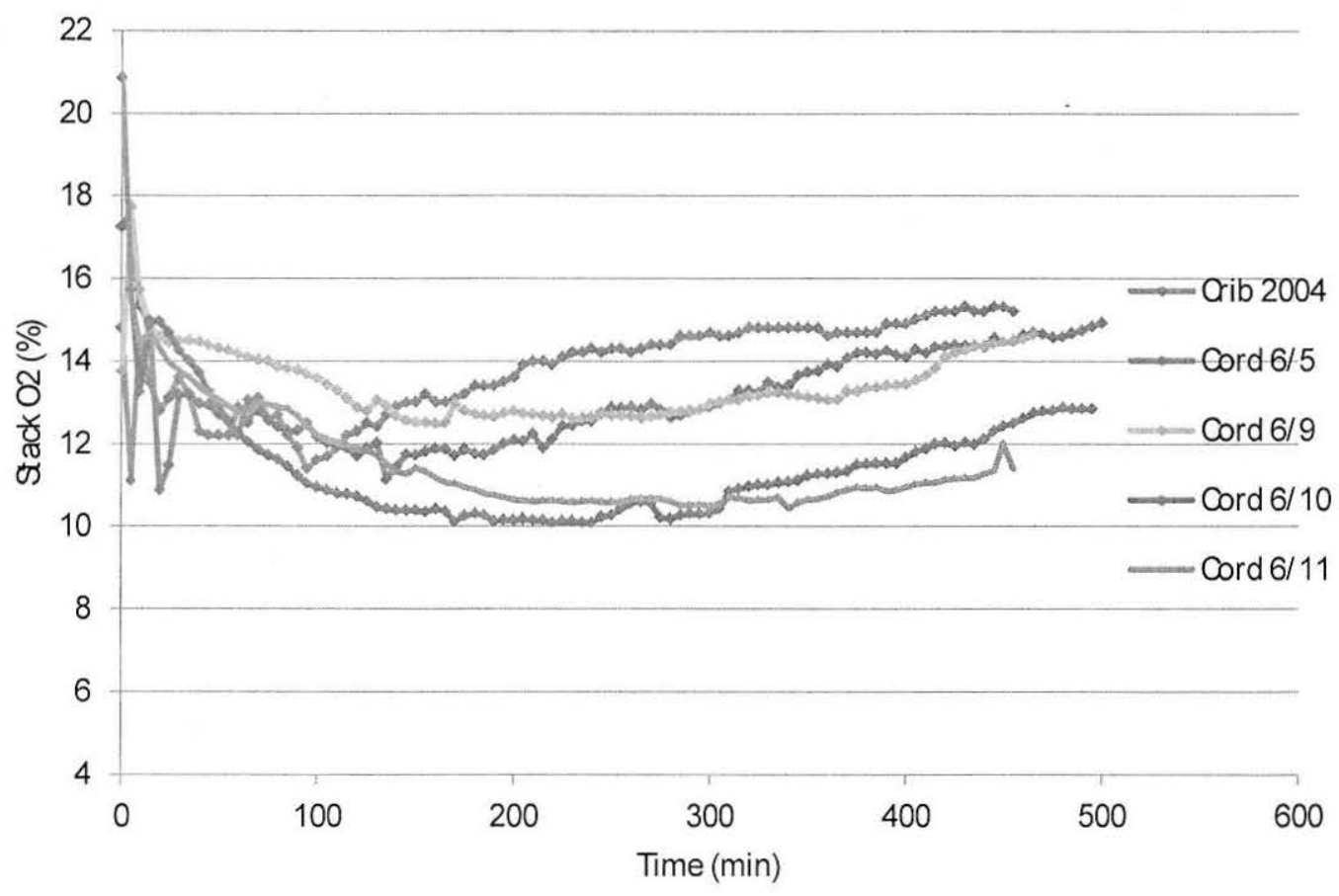

Figure 12: Cat. II stack oxygen trends 


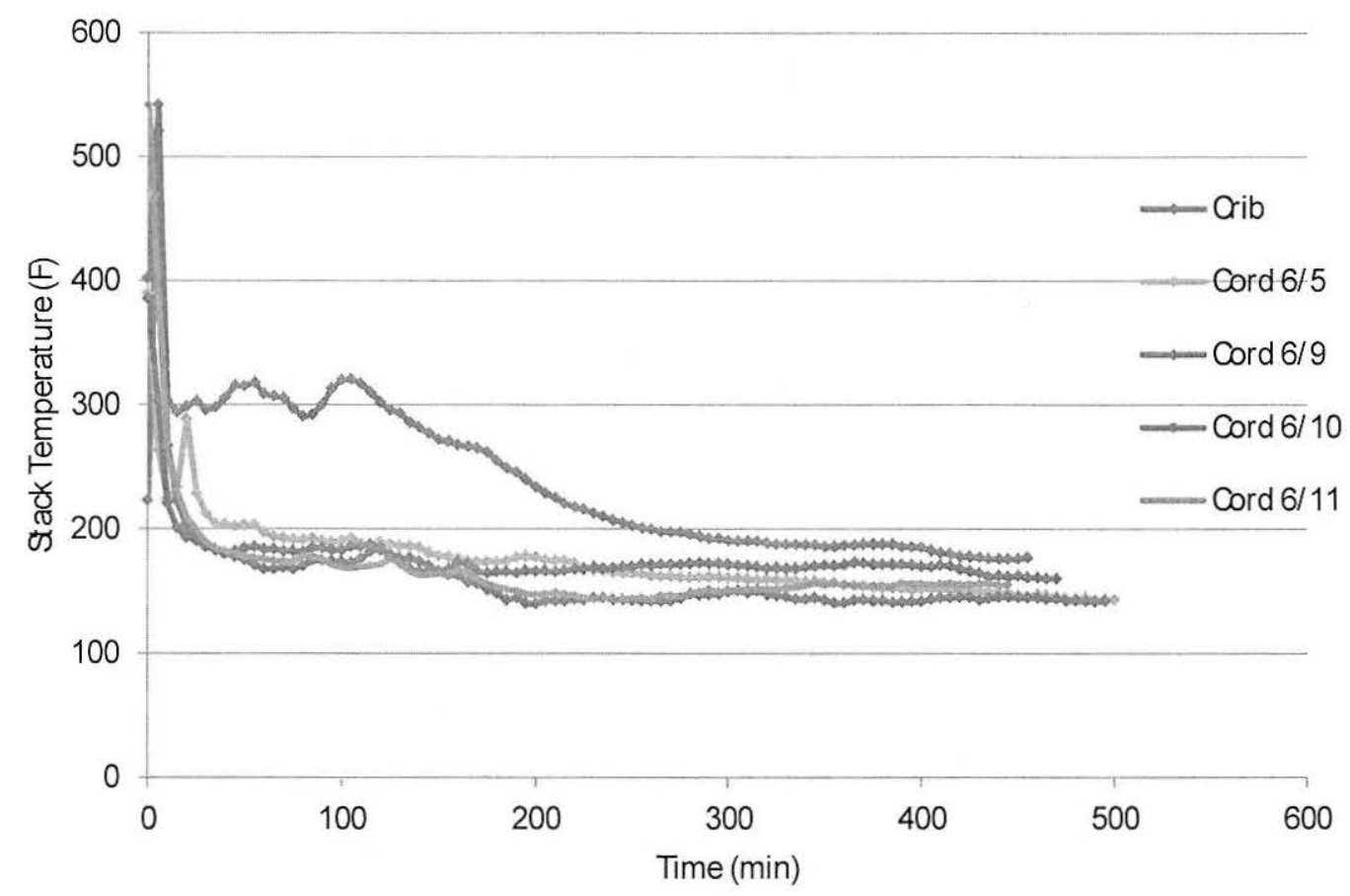

Figure 13: Cat. II stack temperature trends

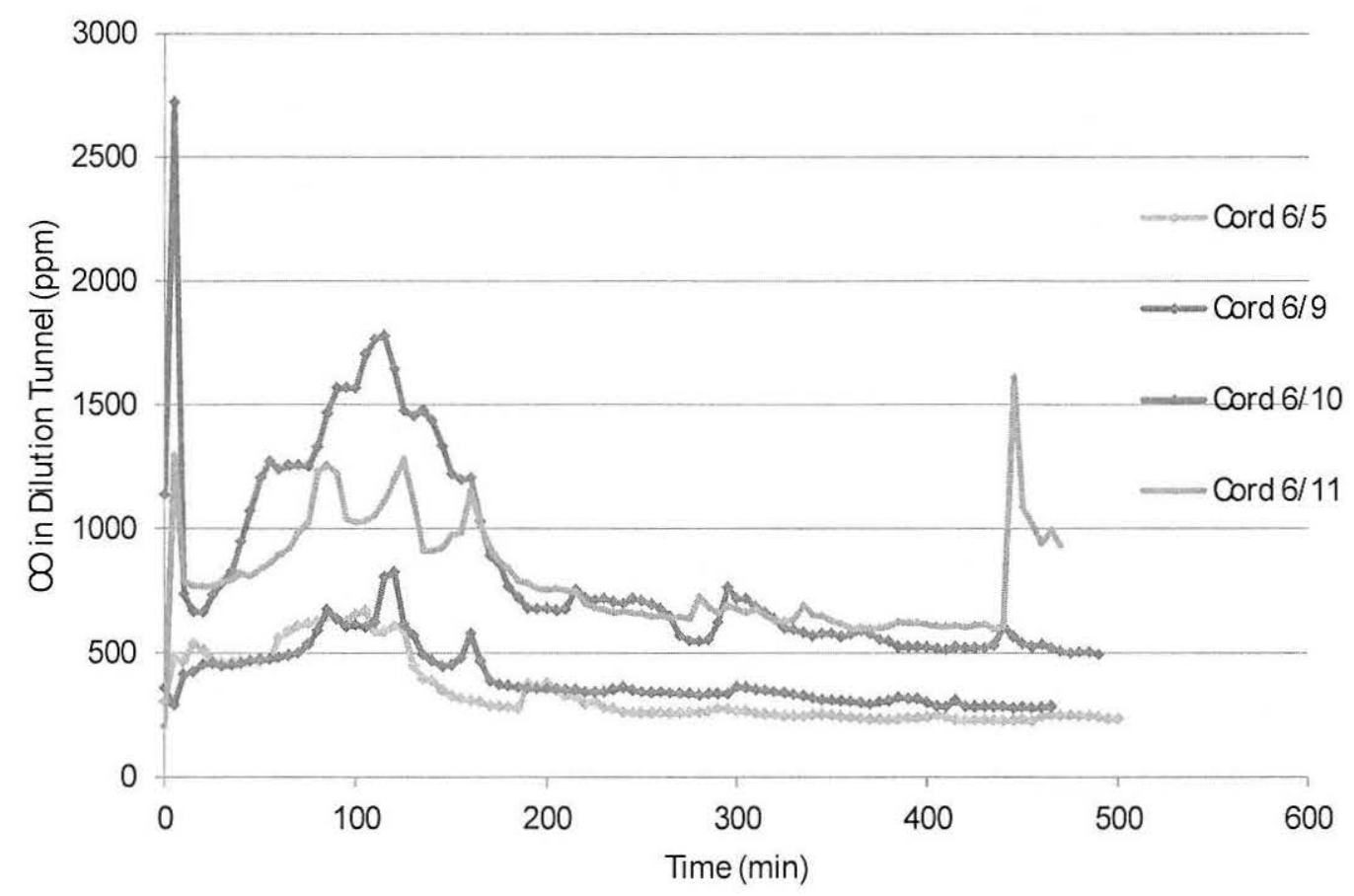

Figure 14: Cat. II carbon monoxide trends 


\section{Wet Cord wood Evaluation}

In an exploratory test a high burn rate test was done using very wet cord wood. This was done specifically to provide an evaluation of the impact that burning very we wood might have on emissions. Test procedures were the same as was followed with the other test fuels. Wood moisture content was $48.4 \%$ on a wet basis. Particulate emissions were found to be extremely high, $50.6 \mathrm{~g} / \mathrm{hr}$ over the run, 11.8 times higher than the average emission rate with the drier test fuel in Category IV.

\section{Discussion}

The test results presented here clearly show much higher emissions with the cord wood tested vs the crib wood results included in the certification test report. This is particularly clear for the low input, Cat II test. The burn rate, flue gas temperature, and flue gas oxygen however, would not lead to the obvious conclusion that the burn characteristics with the cord wood are very much different than with the crib wood. The only notable exception to this is the Cat II test, where the stack temperature was clearly higher for the crib wood tests.

There are several factors which could contribute to the differences observed between the cord and crib wood results:

The cord wood does not have the defined air flow path between the pieces as there is in the crib wood tests. It should be noted that in loading the cord wood into the firebox great effort was taken to space the pieces as per the manufacturer's loading instructions and with spacing between the pieces as uniform as possible.

$\square$ The crib wood tests were done with Douglas Fir while the cord wood used here was red oak. It should be noted that red oak is an acceptable fuel in at least the draft version of the ASTM cord wood protocol being evaluated in this work.

With the specific cord wood used in this test, the shell was drier than the average and the core wetter. This could have affected the burn characteristics.

During the Cat II, low burn rate tests, the glass door on the front of the stove became blackened and considerable carbon deposits were noted in the top of the stove and flue pipe after the test. This observation suggests that there was not adequate air in the primary section during this test. The overall exhaust flue gas oxygen was high, indicating adequate air for combustion, but much of this air may have been entered as secondary air and not contributed to achieving burnout of the semivolatile organics. For optimal performance of this stove on cord wood, some rebalancing of the primary air / secondary air ratio may be required. It is possible as well that the details of the air damper setting and the procedure for loading and the timing of the startup operations contributed to differences between cord wood and reported crib data.

The results in this work can be compared with those of a catalytic stove conducted independently of this work and by a manufacturer. In the case of the catalytic stove, a direct comparison was made between cord and crib wood test results. The emission rate of particulates was found to be 2.2 times higher with cord wood in Category II. At higher burn rates the emissions were closer with the cord wood emission rate $32 \%$ higher. This comparison is made based on direct method $5 \mathrm{G}$ emission measurements. 


\section{Conclusions}

These results indicate that there can be very significant differences between the emissions during certification testing between cord wood and the Method 28 crib wood. In the lowest burn rate tested, the particulate emission rate with cord wood was found to be 18 times higher than was reported with the crib wood testing. 